Ginka Borisova, lowa State University;

Veljko Fotak, Kateryna Holland, William L. Megginson,

University of Oklahoma, USA

\title{
GOVERNMENT OWNERSHIP AND THE COST OF DEBT: EVIDENCE FROM GOVERNMENT INVESTMENTS IN PUBLICLY TRADED FIRMS
}

Contrary to public perceptions and despite the worldwide success of state privatizations, over the past decade governments have acquired more assets through stock purchases (US\$ 969 billion) than they have sold through share issue privatizations and direct sales (US\$ 765 billion). In fact, governments and stateowned entities have been such active stock-market investors that they now own approximately one-fifth of global stock-market capitalization. We investigate the impact of government share ownership on the cost of corporate debt. Government ownership might carry an implicit debt guarantee that reduces the chance of default and, hence, leads to a lower cost of debt. On the other hand, government ownership could lead to a higher cost of debt if this implicit debt guarantee increases moral hazard for managers and if state owners impose social and political goals that reduce corporate profitability and thus increase default risk. Using a sample of 1,278 bonds issued by 214 firms subject to changes in government share ownership from 43 countries over 1990-2010, we find that government ownership is associated with lower spreads during the 2008-2010 financial crisis, during various banking crises, for highly-levered firms, and for non-investment grade bonds. That is, in times of economic recession or firm distress, the dominant effect is the reduction in perceived default risk. Further, we find that the effect is specific to domestic government ownership, also consistent with the notion that the main channel of impact is the debt guarantee, and we document that the impact of government ownership differs by type of government entity. Outside of crises, government ownership generally leads to a higher cost of debt.

Borisova, G. Government ownership and the cost of debt : evidence from government investments in publicly traded firms [Текст] / G. Borisova, V. Fotak, K. Holland, W. L. Megginson // Міжнародна банківська конкуренція : теорія і практика : матеріали VII Міжнародної науково-практичної конференції (2425 травня 2012 року). / Ред. А.О. Спіфанов. - Суми : УАБС НБУ, 2012. - С. $25-26$. 